\title{
OS PASSOS PRELIMINARES DE LACAN EM DIREÇÃO AOS NOMES DO PAI
}

\author{
LACAN'S PRELIMINARY STEPS TOWARDS THE NAMES OF THE FATHER \\ LOS PASOS PRELIMINARES DE LACAN EN DIRECCIÓN A LOS NOMBRES DEL PADRE
}

\author{
Vinicius Moreira Lima* \\ Ângela Maria Resende Vorcaro*
}

\begin{abstract}
RESUMO
Este artigo tenciona percorrer o caminho apontado por Lacan em sua única aula do seminário sobre os nomes do pai, em 1963, que orientaria a direção do ensino daquele ano. Recuperamos as aulas então indicadas, relativas aos Seminários 5, 7 e 9, à luz do que foi desdobrado posteriormente, envolvendo, em especial, a questão do pai e do nome próprio. Articulamos, ainda, as pistas de sua única aula do seminário inacabado com algumas elaborações espalhadas ao longo do Seminário 10, empreitada que nos permite vislumbrar relações do objeto voz com a nominação e com a angústia, apontando para as formulaçóes ulteriores de Lacan sobre a père-version no Seminário 22.
\end{abstract}

Palavras-chave: Objeto a. Voz. Nominação. Nomes do pai.

\begin{abstract}
This article intends to go through the way traced by Lacan in his sole class at the seminar about the names of the father, in 1963, which would guide those who wanted to see in which direction his teaching would advance that year. Thus, we made a reading of the classes indicated by Lacan himself from the Seminars 5, 7, and 9, through the light of what was further elaborated in his theory, involving specially the question of the father and the own name. Later on, we tried to articulate the clues of his only class from the unfinished seminar along with some ideas spread throughout Seminar 10, a work that allows us to foresee the relations of the object voice with the naming and with the overcoming of anxiety, which already points to ulterior formulations of Lacan about père-version in seminar 22.
\end{abstract}

Keywords: Object $a$. Voice. Naming. Names of the father.

\footnotetext{
Texto recebido em 4 de outubro de 2016 e aprovado para publicação em 4 de abril de 2017.

Graduando em Psicologia pela Universidade Federal de Minas Gerais (UFMG), bolsista de iniciação científica (PIBIC/CNPq) na Faculdade de Filosofia e Ciências Humanas (Fafich-UFMG). Endereço: Rua Engenheiro Paulo Fernandes, 39, ap. 602 Bairro Minas-Brasil, Belo Horizonte-MG, Brasil. CEP: 30730-180.E-mail: vmlima6@gmail.com.

${ }^{* *}$ Doutora e mestra em Psicologia Clínica pela Pontifícia Universidade Católica de São Paulo (PUC-SP), professora adjunta no Departamento de Psicologia da UFMG, Fafich-UFMG. Endereço: Rua Paul Bouthilier, 353 - Bairro Comiteco, Belo Horizonte-MG, Brasil. CEP: 30315-010. E-mail: angelavorcaro@uol.com.br.
} 


\section{RESUMEN}

Este artículo intenta trazar el camino apuntado por Lacan en su única clase del seminario sobre los nombres del padre, en 1963, que guiaría la dirección de su enseñanza en ese año. Para tanto, hicimos la lectura de las clases indicadas por el propio Lacan en los Seminarios 5,7 y 9, a la luz de lo que se desplegó después en la teoría, en especial, con la cuestión del padre y la del nombre propio. También articulamos las pistas de su única clase del seminario inacabado con algunas elaboraciones dispersas a lo largo del Seminario 10, trabajo que nos permite vislumbrar las relaciones del objeto voz con la nominación y la superación de la angustia, apuntando para las formulaciones ulteriores de Lacan sobre la père-version en el seminario 22.

Palabras clave: Objeto $a$. Voz. Nominación. Nombres del padre.

\section{INTRODUÇÃO}

E m seu seminário inacabado sobre os Nomes do Pai, Lacan (1963/2005, p. 58), ${ }^{1}$ ciente de que estaria impedido de ministrar seu curso completo naquele ano, registrou algumas orientações. Prometendo nunca mais retomar o tema dos nomes do pai, assinalou balizas orientadoras para aqueles que quisessem situar a direção que teria seu ensino naquele ano. Assim, apontou uma série de liçôes de seminários anteriores, nas quais uma estrutura de pensamento já estaria bastante avançada e as quais ele amarraria nas aulas de 1963.

Suas orientações destacam lições pontuais dentro dos seminários 5, sobre $A s$ formaçôes do inconsciente (Lacan, 1957-1958/1999); 7, sobre A ética da psicanálise (Lacan, 1959-1960/2008); e 9, sobre $A$ identificação (Lacan, 1961-1962/2003). $\mathrm{O}$ percurso que faremos aqui justamente apresenta o trajeto indicado pelo próprio Lacan (1963), na única aula do seu seminário dito "inexistente" (Miller, 2011), à luz do que se desdobrou posteriormente em sua teoria. Em seguida, discutiremos os avanços trazidos sobre a questão do pai nessa mesma aula e, ainda, em algumas das aulas do seminário anterior sobre a angústia (Lacan, $1962-1963 / 2005)$.

\section{OSEMINÁRIO, LIVRO 5: AS FORMAÇŌES DO INCONSCIENTE}

No seminário 5, Lacan (1957-1958) expõe sua leitura sobre a metáfora paterna, que "concerne à função do pai, como se diria em termos de relações inter-humanas” (p. 166). Essa função entrelaçaria o complexo de Édipo ao

1 A primeira data indica o ano de publicação da obra, e a segunda, a edição consultada pelo autor, a qual somente será pontuada na primeira citação da obra no texto. Nas seguintes, será registrada apenas a data de publicação original. 
complexo de castração, encaminhando o sujeito para sua normalização. Assim, torna-se possível "que, de um lado, o menino se transforme em homem, e de outro, a menina se transforme em mulher" (p. 192). Nesse processo, seria necessária a intervenção do pai como portador simbólico do falo, ápice dos três tempos do Édipo.

No primeiro tempo, o do pai velado, "o sujeito se identifica especularmente com aquilo que é o objeto do desejo de sua mãe" (p. 198). Aqui, o que "a criança busca, como desejo de desejo, é poder satisfazer o desejo da mãe" (p. 197), ficando às voltas em ser ou não ser, ela mesma, o falo imaginário da mãe (falo materno). No entanto, para a criança, o vaivém materno é enigmático: algo insondável do desejo materno não se esgota no filho, pois outra coisa, um $x$, mexe com a mãe, deslocando a criança da equivalência a esse falo imaginário. Vale notar, por outro lado, conforme explicitado no seminário $A$ anguistia (Lacan, 1962-1963, p. 353), que a própria criança se angustia por não saber a que esse lugar a reduz.

Entramos no segundo tempo do Édipo, a delimitação da privação da mãe a seu objeto fálico, por meio da localização do agente que a representa: o pai privador, terrível, onipotente. Conforme é mediado pelo discurso materno proibidor, o pai emerge como rival imaginário da criança (p. 209). A intrusão desse elemento impossibilita que o círculo se feche entre o filho e a mãe, apontando para a lei que os ultrapassa e os regula (Outro) interditando a ambos, a assimilação do infans à posição de objeto do desejo da mãe. Reconhecido como suporte da lei, o pai se torna também portador simbólico do falo, passando a orientar a referência identificatória da criança.

No terceiro tempo, o pai se revela como aquele que tem o falo e pode cedê-lo à mãe, restando à criança formar seu Ideal do eu com base numa identificação com esse pai (p. 200). Aqui "se trata de o menino se identificar com o pai como possuidor do pênis, e de a menina reconhecer o homem como aquele que o possui" (p. 203). Pois é no momento da saída do Édipo, dita "normatizadora", que a criança "reconhece não ter — não ter realmente aquilo que tem, no caso do menino, e aquilo que não tem, no caso da menina" (p. 179). Em outros termos, está em jogo a assunção do sexo pelo sujeito, ou seja, a identificação com o tipo ideal de seu sexo. Esse resultado da intervenção do pai como normativo, instaurador e definidor do complexo de Édipo é tratado por Lacan como "socialmente injustificável", visto que não pode ser fundamentado "em nenhuma finalidade social" (p. 204).

Mas, para além dessas normas culturalmente variáveis, Lacan parece isolar outra função, função de amarração, ligada ao registro simbólico. Se, na esfera cultural, o Édipo serve para promover a virilização do menino e a feminização 
da menina (p. 171), há, em outro âmbito, algo que Lacan coloca como uma "necessidade da cadeia significante" (p. 187), portanto estrutural, que não depende da forma cultural. Essa é a posição do Nome-do-Pai como tal. Afinal, se "há uma ordem simbólica, alguma coisa corresponde à função do Nome-doPai” (p. 187).

Porque o pai, culturalmente portador da lei, só é real enquanto as instituições lhe conferem (não seu papel e sua função de pai, mas) "seu nome de pai" (p. 187). A paternidade não é natural; a posição do pai pertence ao simbólico. $\mathrm{O}$ pai é então reduzido a uma metáfora, isto é, "um significante que surge no lugar de outro significante" (p. 180), acrescentando algo na significação. Metaforizando o desejo enigmático da mãe, o pai do complexo de Édipo é, no campo do Outro, o significante que representa "a existência do lugar da cadeia significante como lei” (p. 202). É o pai real (aí entendido como o pai da realidade), mediado pelo discurso da mãe, que, na cultura ocidental, é tradicionalmente responsável pela enunciação da lei.

Nesse movimento da metáfora paterna, o sujeito encontraria, como saldo, uma tranquilização para sua angústia a partir do falo, que, como significante, responderia ao $x$ do desejo enigmático da mãe. Seu engendramento como plus de significação seria uma herança do significante do Nome-do-Pai em sua forma cultural. Isso acarretaria a referida normalização do sujeito, pela identificação às insígnias do pai, portador do falo. A inacessibilidade direta ao falo geraria o Ideal do eu, ponto no horizonte de onde o sujeito poderá reconhecer-se desejável, o que está estreitamente ligado às ficçôes da virilidade e da feminilidade. Lacan salienta tal ficcionalidade: "Na medida em que é viril, um homem é sempre mais ou menos sua própria metáfora. É isso, aliás, que coloca sobre o termo virilidade a sombra de ridículo que, enfim, convém destacar” (p. 201).

Esse relato do desenlace edipiano, de caráter um tanto mítico, é devedor das formações burguesas das sociedades ocidentais modernas, estando atrelado a uma estrutura de ficção. O falo, o ponto de basta, como diz Lacan (19571958), que serve para essa amarração, é "tão somente uma história mística", pois "ninguém jamais pode alinhavar uma significação num significante" (p. 202). Isolava-se aqui, até certo ponto, uma função de amarração que não se confundia com as formas culturais. Mas vale lembrar, como sublinha Porge (2010), que, a despeito de Lacan (1957-1958) tratar o Nome-do-Pai como metáfora ao mesmo tempo em que tratava também o sintoma como metáfora, ele não identificou o Nome-do-Pai ao sintoma, gesto teórico que só se tornou possível muitos anos

$2 \mathrm{O}$ motivo de enfatizarmos o Nome-do-Pai e não apenas Pai ficará mais claro a partir do Seminário 9, pois o nome próprio será visto como capaz de enlaçar o real, articulando-se à função de nominação que carrega consigo o peso do universal. 
depois, após desprender, desde 1960, a problemática do Nome-do-Pai daquela do sintoma (Porge, 2010, p. 10).

\section{O SEMINÁRIO, LIVRO 7: A ÉTICA DA PSICANÁLISE}

No seminário 7, Lacan (1959-1960)³ retoma duas obras freudianas clássicas por tratarem da função do Pai: Totem e tabu (Freud, 1913/2013) e Moisés e o monoteísmo (Freud, 1939/1996). Seu intuito, com essa retomada, é discutir a questão de como foi possível, no mundo egípcio antigo, aflorar a mensagem monoteísta ante uma atmosfera pagã, na qual pululava em todo lugar o numinoso, isto é, o místico, o divino. Com base nos trabalhos de Freud, Lacan relembra que, no século XIV a.C., a religião de Akhenaton defendeu, no Egito, um "unitarismo da energia, simbolizada pelo órgão solar, de onde ela irradia e se espalha pelo mundo" (p. 208). Estava em causa, aí, uma variante do DeusSol chamado Aton, articulado por uma visão racionalista que, no entanto, logo fracassou. Pois, tão logo Akhenaton vem a desaparecer, "o formigamento dos temas religiosos se multiplica" (p. 208). E quem "guarda a tocha dessa visada racionalista" (p. 208) é Moisés, o egípcio, que vem dar continuidade à mensagem de Akhenaton.

Moisés, “o Grande Homem, o legislador” (p. 208), é aquele que ouve surgir da sarça ardente a fala decisiva de um Deus essencialmente escondido: não Eu sou aquele que é, mas Eu sou aquele que sou. Mas o fato de que Moisés não conseguira sustentar o esplendor da face desse Deus permite a conclusão de Lacan de que a sarça ardente era "a Coisa de Moisés" (p. 209): a divindade tipificara o imaginário pelas leis da fala, proibindo a confecção de qualquer imagem sua. Isso talvez se articule a um momento posterior, em que Lacan lembra a assertiva bíblica de que Deus fez o homem à sua imagem, comentando que as imagens são "sempre ocas" (p. 235); elas revelam o vazio de Deus, e é por isso que ele interdita a confecção de sua própria imagem, a despeito de ser nesse mesmo vazio que Deus avança.

Para Freud, Moisés teria sido assassinado pelo seu populacho, no que ele era veículo da mensagem de um Deus único. Esse Deus único seria a herança judaica por excelência, visto que essa mensagem "encontrou-se vinculada, no recalque, ao assassinato do Grande Homem” (p. 209). Na leitura de Lacan, o assassinato primordial do Grande Homem vem emergir num segundo assassinato, o do Cristo, que o traduz e o traz à luz, implicando o ápice da mensagem monoteísta. Esse cenário, portanto, ressoa sobre o fundo do assassinato inaugural da humanidade, o do pai primitivo, narrado em Totem e tabu (Freud, 1913). A tradição judaico-cristã, então, revelaria o crime primitivo da lei primordial.

3 Interessante notar o lapso que Lacan (1963) comete ao indicar, no texto dos Nomes do Pai, as aulas de maio de 1960, quando, aparentemente, referia-se às aulas de março. 
Discutindo o mote nietzschiano da morte de Deus, numa paráfrase freudiana, Lacan sustenta que o assassinato do pai, em vez de abrir acesso ao gozo, reforça sua interdição. Isso porque a transgressão no sentido de gozo apoia-se na Lei, apontando o nó estreito entre Lei e desejo. Mas o mito do assassinato do pai é o mito de um tempo para o qual Deus está morto. E, se Deus está morto para nós, é porque o está desde sempre: "Ele nunca foi o pai, senão na mitologia do filho" (Lacan, 1959-1960, p. 213). É por Deus estar morto desde sempre que uma mensagem pôde ser veiculada nas crenças que resgatam sua presença.

Essa é a mensagem do Deus único de Akhenaton, que "regula a ordem do real" (p. 216). Tal Deus é o mesmo da mensagem secreta que o povo judeu veicula, visto que, assassinando Moisés, o povo judeu reproduz o assassinato arcaico do pai. Na tradição judaico-cristã, o Deus dos fiéis conserva a mensagem do Deus de Akhenaton, emergindo como um "Deus-sintoma" (p. 217) que veicula a verdade de Deus: a natureza humana do Pai. É o que a Coisa de Moisés comprova, ao falar a ele na sarça ardente, sem se fazer de Deus único, mas afirmando-se como um Deus à parte, diante do qual os outros não poderiam ser levados em consideração. Não é que fosse proibido honrar outros deuses; só não se deveria fazê-lo em presença do Deus de Israel.

Trazendo à baila seus conceitos de Nome-do-Pai e de pai real, Lacan considera que a obra freudiana não negligencia nenhum dos dois. Quanto ao primeiro conceito, diz que, para Freud, "Na história humana o reconhecimento da função do Pai é uma sublimação, essencial à abertura de uma espiritualidade que representa como tal uma novidade, um passo na apreensão da realidade como tal" (p. 217). Quanto ao segundo, sustenta que, também para Freud, "é desejável que no decurso de toda aventura do sujeito haja, se não o Pai como um Deus, pelo menos como um bom pai” (pp. 217-218).

A presença desse bom pai, em Freud, possibilita a identificação viril do menino, que tem como condição o amor pelo pai, o que aponta para o papel deste na normalização do desejo. Mas esse efeito só se produz se tudo está em ordem do lado do Nome-do-Pai, isto é, do Deus que não existe. Isso gera para o pai uma posição singularmente difícil, tornando-o sempre um personagem manco.

Assim, a morte de Deus se articula firmemente à problemática do $S(\AA)$, significante do Outro barrado, que é a resposta derradeira à garantia pedida ao Outro, apontando para a ausência de garantia do sentido dessa lei mais profundamente articulada no inconsciente. "Se nada mais há senão a falta (manque), o Outro se esvai, e o significante é o significante da morte" (p. 231). Nisso se introduz o paradoxo do gozo, visto que o cristianismo é um drama 
que encarna literalmente a morte de Deus, a qual, longe de tornar possível o acesso ao gozo, reforça a Lei, a interdição, instaurando o mandamento cristão do "Amarás teu próximo como a ti mesmo".

Em suma, no rastro de Freud, Lacan concebe o monoteísmo como sintoma do assassinato mítico do pai, drama do neurótico por excelência, assassinato que é uma mitologia do filho, e do filho apenas, fundante de seu regime psíquico. Interessante notar que esse Deus de Moisés não nega a existência de outros deuses, tampouco permite a confecção de imagens suas, pois imagens são ocas; isso parece apontar para o fato de haver uma multiplicidade de amarraçôes possíveis, e não apenas uma única, que seria baseada na substancialização do termo Nomedo-Pai. Considerando que nenhum nome é próprio ao Pai, este se reduz a uma função, que pode ser exercida por diversas nominaçôes possíveis, uma vez que não há garantia dada pelo Outro para essas amarrações, $S(\AA)$. Se o fundamental, para Lacan, é encontrar um pai que cumpra bem essa função, esse parece ser um dos caminhos lacanianos rumo ao desdobramento do Nome-do-Pai.

\section{O SEMINÁRIO, LIVRO 9: A IDENTIFICAÇÃO}

No seminário 9, Lacan (1961-1962) analisa a função do nome próprio para a constituição do sujeito, pensado em termos estruturais. É a partir do traço unário que se chega ao nome próprio, por meio da identificação regressiva ao traço unário do Outro. Discutindo as formulações de teóricos como Russell, Gardiner e Mill, e articulando as relações da fala com a escrita, Lacan avança que a definição do nome próprio depende da relação da emissão nomeadora com algo que, em sua natureza radical, é da ordem da letra.

Para o psicanalista, o advento da escrita se dá conforme alguma coisa que já é escrita, o isolamento do traço significante, sendo nomeada, vem a poder servir como suporte do som do nome próprio. A escrita como material, como bagagem, esperava para ser fonetizada. Uma vez que é vocalizada, fonetizada, a escrita aprende a funcionar como escrita. Assim, uma das características do nome próprio é relacionada a esse traço de sua ligação à escrita, que, de uma língua para outra, conserva sua estrutura até mesmo sonora. É aí que se insere a função do sujeito no sentido estrutural, visto que, mesmo em outras línguas, essa estrutura sonora é respeitada, "e isso em razão da afinidade justamente do nome próprio com a marca, com a designação direta do significante como objeto" (p. 94).

Nesse caso, uma das raízes da estrutura de onde se constitui a linguagem é essa leitura dos signos que já aparecem antes de todo uso da escrita que, posteriormente, 
servirão de suporte fonético à modulação falante. A presença desses signos toca a radicalidade do "enlaçamento da linguagem com o real" (p. 97). Tal problema se coloca porque, para compreender a linguagem, é primeiramente necessário ordená-la por uma referência a si mesma, a seus próprios valores estruturais, para que ela seja capaz de funcionar fora de toda consciência do sujeito.

Seguindo nessa esteira, é preciso estabelecer a junção do funcionamento da linguagem com aquela coisa que, no real, leva sua marca. Houve, num tempo recuperável, um momento em que alguma coisa estava ali para ser lida com a linguagem, quando ainda não havia escrita. É pela inversão dessa relação de leitura do signo que pode nascer, em seguida, a escrita que serviu para conotar a fonetização.

O nome próprio especifica o enraizamento do sujeito, sendo, mais especialmente do que qualquer outro nome, o que já está pronto na língua para receber essa informação do traço. Se o nome próprio ainda traz a marca disso sob a forma do que não se traduz, mas apenas se transpõe, se transfere, é aqui que reside a propriedade particular do nome próprio na significação. Nesse ponto radical, arcaico, Lacan supõe a origem do inconsciente. Enquanto o sujeito fala, ele só pode avançar mais adiante na cadeia, no desenrolar dos enunciados. Mas, dirigindo-se aos enunciados, ele elide algo na enunciação que ele não pode saber: o nome do que ele é como sujeito da enunciação. No ato da enunciação, há essa nominação latente, concebível como primeiro núcleo, como significante do que em seguida vai se organizar como cadeia giratória desse centro do coração falante do sujeito, isto é, do inconsciente: conforme o sujeito fala, nomeia-se sem saber por qual nome.

Problematizando, por meio do quadrante lógico de Peirce, as proposições universais aristotélicas (Todo e Nenhum) como incapazes de determinar qualquer existência, Lacan assevera a dependência da existência à presença de algum particular efetivo. Assim, considera que "o Nome-do-Pai é essa alguma coisa que, ao mesmo tempo, tem seu valor universal, mas que remete a você e ao outro o encargo de controlar se há um pai ou não dessa natureza" (p. 128). Nesse sentido, "na ambiguidade do suporte particular que podemos dar no engajamento da nossa palavra ao Nome-do-Pai como tal" (p. 131), não há nada de humano que seja "completamente desembaraçado do Nome-do-Pai" (p. 131). Assim, levando em conta o setor vazio do quadrante lógico em que não há existência, é justamente em razão desse espaço de pura perda, do pai não pai, que se pode julgar uma categoria particular. A afirmação "aquele é meu pai” não franqueia o significado do pai para o sujeito. Seu verdadeiro suporte é "um suporte algoritmo a sua existência de sujeito como tal" (p. 131). Estamos implicados, portanto, numa discussão já muito avançada a respeito da função 
das nominações para a amarração psíquica de um sujeito, no que um nome próprio é capaz de bordejar o impossível do real, em suas relações com a função dita do pai.

\section{O SEMINÁRIO, LIVRO 10: A ANGÚSTIA}

$\mathrm{Na}$ última aula do seminário sobre a angústia, intitulada por Miller "Do $a$ aos Nomes do Pai”, Lacan (1962-1963) assinala a direção em que caminharia no seminário seguinte. Para isso, entrará em consideração o objeto $a$ como "primeiro suporte da subjetivação na relação com o Outro" (p. 356), isto é, aquilo "através de que o sujeito é inicialmente solicitado pelo Outro a se manifestar como sujeito" (p. 356), pois o sujeito "só pode entrar no mundo como resto, como irredutível em relação ao que lhe é imposto pela marca simbólica" (p. 356), portanto, resistente à significantização.

Mas essa concepção do sujeito como resto, objeto $a$ em sua existência mais radical, não é sem angústia, pois a função angustiante do desejo do Outro se liga a "eu não saber que objeto a sou eu para esse desejo" (p. 353). No entanto isso só é válido no nível escópico, uma vez que o sujeito desconhece o objeto a que ele é, perante o olhar do semelhante. Esse nível, em que a angústia se aloca por excelência, atinge a forma exemplar do desejo humano como desejo do Outro. Ainda assim, é apenas no nível invocante, "que deve emergir, numa forma pura, o desejo no Outro" (p. 318).

Isso significa que, no nível da voz, "o $a$ volta a se recortar, aqui abertamente alienado, como suporte do desejo do Outro, que dessa vez é nomeado" (p. 365, grifos nossos). O que há de próprio no nível da voz é, portanto, a implicação de uma nominação, articulada com a voz e com a dimensão auditiva, a partir da asserção de que a voz ressoa no vazio do Outro, o vazio estrutural de sua falta de garantia, $S(\AA)$. A voz responde ao que é dito, mas, para que responda "por" isso, deve-se "incorporar" a voz como "a alteridade do que é dito" (p. 300), visto que algum significado, $s(\mathrm{~A})$, deverá daí ser gerado para o sujeito. Assim, em sua função de modelar o vazio, a voz se articula levando em conta os ecos de sua verdade no real: a incorporação da voz traz também as marcas de real que ela arrasta consigo, culminando na produção de uma significação $-s(\mathrm{~A})$ para o sujeito.

O desconhecimento do a como tal deixa a porta aberta para ser situado no campo do Outro, pois só há "superação da angústia quando o Outro é nomeado. Só existe amor por um nome" (p. 366, grifos nossos), que assinala a marca "de

4 Assinalamos que Lacan faz valer a voz com a mesma operação de “incorporação" pelo sujeito em que Freud (1921/1996, p. 115) distingue a primeira identificação com o pai, que acontece por incorporação. 
algo que vai da existência do a à sua passagem para a história" (p. 366). Assim, se, no nível escópico, encontramos a angústia por excelência, no nível invocante, por sua vez, essa angústia poderá ser superada por meio de uma operação de nominação, que implicará a dimensão auditiva, mas também a "função paterna" (p. 365), algo que aponta para o pai como nome e para o pai como nomeante, a partir da identificação da criança, que Freud (1921/1996) define como "a forma mais primitiva e original do laço emocional" (p. 116).

Para essa discussão, Lacan (1962-1963, p. 365) relembra a tensão entre o pai do mito freudiano, cujo desejo "invade, esmaga impóe-se a todos os outros", e a experiência analítica, em que o pai é, diversamente, aquele por meio do qual se efetua "a normalização do desejo nos caminhos da lei". Interessa a manutenção dessa tensão em que Lacan constata que, "na manifestação de seu desejo, o pai sabe a que $a$ seu desejo se refere" (p. 365), isto é, a criança concebe que o desejo desse pai é orientado por alguma coisa. O pai, aqui, não é, como no mito religioso, causa sui, causa de si mesmo; antes, o pai é "o sujeito que foi longe o bastante na realização de seu desejo para reintegrá-lo em sua causa, seja ela qual for, para reintegrá-lo no que há de irredutível na função do $a$ " (pp. 365-366).

É impossível ao sujeito encontrar sua causa em si mesmo no nível do desejo, embora a fantasia da causa sui (de um ser para quem sua causa não lhe seria estranha) seja justamente uma tentativa de superar esse dado de nossa condição: "o de que a causa de seu desejo, o ser humano está desde logo sujeito a têla produzido num perigo que ele desconhece" (p. 358). Esse tema, que parece apontar para as formulações ulteriores da père-version (Lacan, 1973-1974), será retomado por Lacan na sua aula de introdução aos Nomes do Pai.

\section{A AULA DE INTRODUÇÃO AOS NOMES DO PAI}

O passo seguinte na concepção dos nomes do pai, esboçada na aula de 20 de novembro de 1963, encadeia-se ao seminário da angústia, no que a angústia deve ser substituída, para o sujeito, pelo desejo, por meio da operação do objeto $a$. Assim, Lacan (1963) quer traçar um caminho que ultrapasse o mito do assassinato do pai, pois "se toda a teoria e práxis da psicanálise nos parecem atualmente em pane, é por não terem ousado, nessa questão, ir mais longe que Freud” (p. 72).

Para traçar seu caminho, Lacan retoma sua crítica à noção de causa sui: não pode haver causa senão depois da emergência do desejo, e a causa só pode ser encontrada num movimento de remissão a alguma alteridade. Assim, a alteridade do dito, no nível invocante do $a$, comporá aí um papel essencial, uma vez que ela pode indicar que o Outro é, não apenas lugar da miragem, mas também "o lugar onde isso fala" (p. 71). É o que aponta para uma função estrutural do Outro como 
sujeito, como alteridade real do dito. ${ }^{5}$ Para chegar a isso, assinalando a "questão do pai” (p. 72), Lacan afirma a necessidade de ir mais além dela, colocando o problema do "sujeito anterior à questão" (p. 72), que é, ao que nos parece, algo de próprio ao objeto $a$ paterno, transmitido, por incorporação, na primeira identificação do sujeito. Aqui, o pequeno a é "aquilo cuja voz é assumida pelo sujeito a cada vez que fala" (p. 71), um eco dessa alteridade real que fez uma marca significante no sujeito.

Bordejando mais uma vez a ideia da superação da angústia pela nominação, tocamos também o avanço de Lacan sobre o pai, que, se por um lado, é relacionado, no mito freudiano, ao animal, anterior ao interdito do incesto, em sua satisfação irrefreável, por outro, o pai precisa ser articulado à "função do nome próprio" (p. 73). Porque, retomando o trabalhado no seminário 9, o nome é "uma marca já aberta à leitura - eis por que ela será lida da mesma forma em todas as línguas - impressa sobre alguma coisa que pode ser um sujeito que vai falar, mas que não falará de modo algum obrigatoriamente" (p. 74). É o que implica a existência, no enunciado, de algo elidido, que é o nome do sujeito enquanto enunciação; isto é, seu inconsciente, em alteridade ao eu e em seu comando.

Lacan relaciona o nome à marca inscrita numa cerâmica egípcia: "A cerâmica nunca teve oportunidade de tomar a palavra para dizer que aquela é sua marca de fábrica. É nesse nível que o nome se situa” (p. 74), ou seja, no nível da enunciação, do elidido no enunciado. Para alcançar esse lugar, para que haja uma nominação, algo deve ser concedido num pacto. É em sua direção que o psicanalista avança, retomando o que se depositou na tradição, da aliança de Deus com o povo judeu, seja suspendendo o sacrifício do filho de Abraão que ele mesmo havia imposto, seja guiando Moisés no Êxodo rumo à terra prometida, circunstâncias de pacto eternizado pelo chofar, que exprime a voz divina e com a circuncisão que testemunha o sacrifício. Pelo que se decanta dos rituais que "co-memoram" o pacto entre Deus e o povo judaico, o objetivo de Lacan nos parece ser a localização do que o objeto $a$ invocante transmite do Outro real ao sujeito e a implicação do próprio sujeito no que, dele, ele oferece ao Outro. A circuncisão é uma extração na carne que opera a inserção do sujeito, filiando-o a uma tradição, a partir da cessão de uma parte do corpo ao Outro, à maneira do objeto $a$, reconhecendo uma dívida simbólica. Já o chofar, cujo sopro anuncia a presença de Deus, resgata e rememora a aliança do povo com Deus: por meio da voz, Deus comparece cobrando e confirmando o pacto, função paterna que nomeia o desejo do Outro e tranquiliza a angústia.

\footnotetext{
5 A noção de Outro real foi até então tratada por Lacan nos Seminários 5, 6, 9 e 10, além de, posteriormente, referir-se a ela nos Seminários 17 e 22. O Outro como sujeito, como "Outro implicado no gozo, que é o Outro real" (Lacan, 1962-1963, p. 201), implica a especificidade singular do sujeito que mobiliza a implantação do Outro simbólico.
} 
Ao retornar a Moisés, Lacan (1963) assegura: o "Sou aquele que sou com que Deus afirma-se idêntico ao Ser, motiva um puro absurdo quando se trata do Deus que fala a Moisés na sarça ardente” (p. 65), uma vez que esse Deus se apresenta a Moisés como desejante, à maneira humana de um pai, pèrevertidamente orientado. Porque, como indica, em outro lugar, Lacan (19601961/1992, p. 374), é nessa mesma sarça ardente que deve ser localizado o lugar de $a$, o objeto do desejo, a Coisa de Moisés, no que a opaca e misteriosa resposta "Sou aquele que sou" ressoa de modo enigmático, à maneira de um "Che vuoi?" que escutamos sem saber quem fala.

Lacan (1963) comenta o Êxodo, ${ }^{6}$ capítulo 3, na cena em que Deus, ou Eloim, diz a Moisés: "Quando fores em direção a eles, irás dizer-lhes que me chamo Ehyeh asher ehyeh, Eu sou aquele que sou" (p. 77). Assim, já se trata de um Deus que tem um desejo orientado. Porém, discutindo o ponto de furo na circularidade dessa resposta divina, Lacan afirma que o único sentido atribuível ao Eu sou é o Nome Eu sou. “Mas não foi sob esse Nome', diz o Eloim a Moisés, 'que me anunciei a teus ancestrais"” (p. 77). Esse Deus, que era o mesmo Deus de Abraão, Isaac e Jacó, anunciou-se a eles sob um Nome pelo qual o Eloim da sarça ardente o chama: El Shaddai, que tradicionalmente se traduz como "o Todo-Poderoso", mas que Lacan (1971-1972/2011), em outro lugar, indica como "o nome com que se designa aquele cujo nome não se diz" (p. 207).

Se esse Nome é impronunciável, é porque "um Deus, isso se encontra no real. Como todo real é inacessível, isso se assinala pelo que não engana, a angústia” (Lacan, 1963, p. 78). Mas o Deus da tradição judaico-cristã fará, por meio de um pacto, justamente o caminho que vai do gozo ao desejo, tal como Lacan situa o percurso do objeto $a$ no seminário da angústia (gozo/angústia/desejo). Para ilustrá-lo, o psicanalista remete ao relato bíblico do sacrifício de Abraão, também chamado Akedah, que significa "ligadura" (p. 79). A tradição, em que Lacan reconhece o gozo de Deus, conta que Abraão recebe um chamado de Deus para que sacrificasse, por sua vontade, seu filho Isaac. No entanto, quando o pai levanta a faca, um anjo que figura a "presença daquele cujo Nome não é pronunciado” (p. 80), retém o braço de Abraão, a título de El Shaddaí.

À época, eram comuns os sacrifícios, e El Shaddai prova aí seu poder, que já fora antes exercido ao "tirar Abraão do meio de seus irmãos e de seus pares" (p. 81). Mesmo assim, "El Shaddai não é a Onipotência, que cessa no limite do território de seu povo" (p. 82). Entretanto, "El Shaddai é aquele que elege, aquele que promete e que faz passar por seu nome uma certa aliança, que é transmissível de uma única forma, pela baraka paterna” (p. 82). Considerando que baraka significa a continuidade de um poder ou uma presença espiritual transmitida 
hereditariamente, pode-se notar a analogia referente a uma transmissão feita pelo pai, à maneira da função paterna, lida como père-version (Lacan, 1973-74): uma versão paterna do $a$.

No entanto, diante da mudança de decisão de El Shaddaí, Abraão teria insistido em fazer "ao menos um leve ferimento, para sair um pouco de sangue" (Lacan, 1963, p. 83), perguntando: "Isso te dará prazer, Eloim?" (p. 83), o que apontaria para o gozo perverso desse Deus.

Esse ferimento, porém, não será feito em Isaac; o que acontece é o sacrifício simbólico de um cordeiro, que lá estaria desde a Criação. Vale notar também que Abraão amarrara seu filho à maneira de um cordeiro, atando os pés e mãos, para o sacrifício. Assim, parece haver uma espécie de continuidade metafórica entre o filho e o cordeiro. Mas não é entre eles que essa metáfora realmente se passa: se o pai, miticamente, é um animal, o Cordeiro primordial, que, se estava ali desde os sete dias da Criação, é também um Eloim. E El Shaddaí designa esse cordeiro para ser sacrificado no lugar de Isaac, visto que tal animal é um ancestral epônimo de Deus. Posteriormente, Lacan (1971-1972) afirma que, "o que é sacrificado no sacrifício de Abraão é, efetivamente, o Pai, o qual não é outro senão um carneiro. Como em toda linhagem humana que se respeita, sua descendência mítica é animal” (p. 196).

O animal como metáfora do pai, portanto, não surge primariamente no nível na fobia, e sim no nível dos ancestrais honrados, que vêm marcar a queda da origem biológica no humano. Entretanto isso não se dá pelo sacrifício real do cordeiro, mas pelo sacrifício simbólico de seu chifre, o "chofar", que lhe é arrancado (Lacan, 1963, p. 83). Mas esse chofar arrancado vem selar um pacto que, para ser compreendido, demanda outra incursão no seminário 10, visto que o chofar revela a "função de sustentação que liga o desejo à angústia no que é seu derradeiro nó" (Lacan, 1962-1963, p. 268).

O chofar é um chifre de formato fálico em que se sopra e que faz ouvir um som (Lacan, 1962-1963, p. 268). Mas é preciso identificar como e em que nível o chofar e a voz podem remeter à função fálica. Para isso, Lacan começa discutindo algumas passagens bíblicas, que mencionam a presença do chofar num diálogo tonitruante entre Moisés e o Senhor, "muito enigmaticamente estendido numa espécie de tumulto imenso, de verdadeira tempestade de ruídos" (p. 271), mas também nota o uso do chofar quando se trata de renovar a aliança com Deus em algum novo conflito. É nisso que esse instrumento parece realmente ser a voz de Javé, a voz do próprio Deus (p. 273). Essa formulação "nos indica o que completa a relação do sujeito com o significante" (p. 273, grifos nossos), isto é, algo de uma alteridade real que nos coloca perante uma das formas do $a$ : uma dimensão 
vocal, emissível, em termos corporais, mas que permite uma nominação para o desejo do sujeito, isto é, desejo do Outro.

Ao que parece, tratamos aqui daquilo em que a emissão de um nome próprio é capaz de enlaçar o real e carregar consigo os ecos de sua verdade, a partir da alteridade do que é dito, que possibilitará uma abertura para o desejo, em superação ao real da angústia. Pois o som do chofar é a lembrança da Akedah, ligadura que se passa no momento exato do sacrifício de Abraão, em que Deus segura a mão de Abraão com a faca e substitui a vítima, Isaac, pelo cordeiro. $\mathrm{O}$ som do chofar sustenta a lembrança desse pacto, e mesmo para o próprio Deus (p. 274). Assim, o que se faz ouvir nesse som é um "mugido de touro abatido do pai” (p. 279), isto é, o mito do assassinato do pai.

Entretanto, se esse mito vem figurar a interdição do incesto, Lacan acrescenta, tal "desejo original" aí referido só pode ser secundário em relação a esse "objeto essencial que exerce a função do $a$, a voz, e aquilo que sua função introduz de dimensões novas na relação do desejo com a angústia” (p. 279). Pois, antes mesmo de o bebê saber que a linguagem serve também para comunicar, "é do Outro que o sujeito recebe sua própria mensagem” (p. 296); a primeira emergência é apenas um "quem sou eu?" inconsciente, posto que não formulável, ao qual responde, antes que o formule, um "tu és". Ou seja, "primeiro o sujeito recebe sua própria mensagem, sob forma invertida" (p. 297). Mas, mesmo que esse "tu és" seja primeiro sem atributo, "por mais interrompida, por mais insuficiente que seja essa mensagem, ela nunca é amorfa, porque a linguagem existe no real” (p. 297).

Uma vez que essa linguagem carrega algo do real, é numa voz desligada de seu suporte que devemos procurar o resto $a$ quanto ao sujeito em vias de se constituir (p. 298). É aqui que reencontramos o chofar: ele só pode servir de modelo do lugar da angústia depois que o desejo do Outro assumiu a forma de uma ordem, sendo inserido no circuito da demanda. Também o chofar pode dar à angústia sua resolução, com a introdução de uma outra ordem (p. 301). Parece-nos que se trata aqui de, diante da angústia do sujeito, ao não saber que objeto $a$ ele é perante o olhar do Outro, haver, em seguida, uma nominação que enlace o real e tranquilize a angústia, constituindo um ser de desejo.

Porque algo do desejo do Outro está implicado nisto: em que eu não sei o que, do Outro, articula-se no chofar, ou seja, na voz, e encobre a angústia (p. 302). Mas essa captura do Outro na rede do desejo é justamente o que está em jogo em um sacrifício; oferecemos ao Outro a mutilação de uma parte (o a), e isso vem selar um pacto, tal como a função paterna. Com a narrativa do sacrifício de Abraão, marcamos o gume da faca entre o gozo e o desejo de Deus (Lacan, 1963, p. 85). Se, de um lado, o Deus dos filósofos é um Deus sujeito suposto 
saber, do outro, o Deus dos fiéis, de Abraão, Isaac e Jacó, é um Deus desejante, um Deus que tem relação com o gozo. E o hebraico valoriza precisamente a hiância que separa gozo e desejo, o sacrifício, cujo símbolo se presentifica na lei da circuncisão. E esta "gera, como sinal da aliança do povo com o desejo daquele que o elegeu, esse pequeno pedaço de carne cortada" (p. 85), que é o $a$, resto da castração, operação de entrada do sujeito na linguagem.

A circuncisão emerge, na tradição, como sacrifício que lastreia a lei comprometendo o sujeito numa dívida simbólica, comemorada pelo chofar. Este seria, em cada infans, o lugar do objeto $a$ vocal, que nomeia o vazio do Outro $[S(\AA)]$ a partir do qual a angústia pode ser ultrapassada para constituir um ser de desejo. A nominação do desejo do Outro real pode dar tratamento à angústia, sendo ressublinhada no nome próprio, que indica o pacto com o Nome-do-Pai. É nisso que o desejo normal se conjuga no mesmo nível que o desejo pai-vertido, père-version. A suposição do gozo puro do pai primordial, da qual nascem em conjunto a Lei e o desejo, faz assumir seu valor na função da versão paterna, em sua relação com o desejo do Outro real.

Pois a perversão "representa o ato de pôr contra a parede a apreensão ao pé da letra da função do Pai, do Ser Supremo. O Deus Eterno tomado ao pé da letra [... ] de seu desejo como interessado na ordem do mundo" (p. 75), é aí que, petrificando sua angústia, o perverso se instala. O que nos parece, mais uma vez, já apontar para o horizonte da père-version, a pai-versão, articulada a uma nominação que garante para o sujeito uma amarração baseada em "uma" versão da causa do desejo, uma versão de $a$, de um pai que seja, efetivamente, "um" bom pai, uma orientação possível, no que a herança paterna é precisamente seu pecado.

\section{CONCLUSÕES}

Com base nessas elaborações, fica patente que Lacan (1963) não se deixou limitar "ao Pai deles, os Padres da Igreja" (p. 64), visto que pautou seu ensino em torno do "modo sob o qual o desejo do Outro é apreendido pelo sujeito" (p. 66). Ainda assim, mantendo silêncio sobre seu seminário de 1963, ele nunca mais retomou o tema diretamente, mas pôde contentar-se "em formular as coisas no nível da estrutura lógica" (Lacan, 1971-1972, p. 102). Para isso, não mais centralizou o Nome-do-Pai como um significante substancial, mas relativizou-o a ser uma nominação que cumpre uma função de amarração para um sujeito. Do Nome-do-Pai, com maiúsculas e hífen, passamos aos nomes do pai, com minúsculas e sem hífen, tal como os encontramos desenvolvidos com os nós borromeanos na década de 70, no seminário 21, Les non-dupes errent (Lacan, 
1973-1974), homófono a les noms du père, e articulados às nominações no seminário 22, RSI, homófono a hérésie, heresia de Lacan no que tange à doutrina freudiana do pai (Lacan, 1974-1975).

Assim, não sendo mais atrelado a uma figura do complexo de Édipo, como era desde Freud, o pai sofre modificações profundas em Lacan. Se, no Seminário 5, o pai já havia se reduzido a uma metáfora, mais tarde, no Seminário 22, ele é considerado como o toro a mais que cumpre o papel de manter unidos os três elos do Real, Simbólico e Imaginário. Para Lacan, Freud não soube prescindir do Pai, ao considerar o Édipo como o único meio de estruturação subjetiva. Já Lacan pôde isolar o Édipo como um modo de suplência, de amarração possível, a dar corpo à realidade psíquica como quarto termo que ata os três registros do nó borromeano. É esse quarto elo que se torna a função paterna de amarração na psicanálise lacaniana, permitindo o gesto teórico que pluraliza os nomes do pai.

Isso implica que o pai passa a ter a ver com uma função pela qual se transmite ao sujeito algo de uma versão de $a$, uma pai-versão do desejo. "Um pai só tem direito ao respeito, senão ao amor, se o dito amor, se o dito respeito, estiver [. . .] père-vertidamente orientado", isto é, direcionado para um objeto pequeno $a$ que causa seu desejo (Lacan, 1974-1975). ${ }^{7}$ Por isso, o pai como nome e como nomeador, ao comportar um número indefinido de nomes do pai, sustenta o buraco do "eu sou o que sou". Assim, ele tem tantos e tantos nomes quantos forem os suportes de sua função. É o que permitirá a Lacan afirmar, enfim, que "vocês são, todos e cada um de vocês, tão inconsistentes quanto os seus pais, mas é justamente pelo fato de tanto estarem inteiramente suspensos neles que vocês estão no estado presente" (Lacan, 1974-1975). ${ }^{8}$ 


\section{REFERÊNCIAS}

Freud, S. (1913/2013). Totem e tabu. In Sigmund Freud: obras completas. (Vol. 11). São Paulo: Companhia das Letras, 2013. (Publicado originalmente em 1913).

Freud, S. (1921/1996). Psicologia de grupo e a análise do ego. In C. M. Oiticica (Trad.), Edição standard brasileira das obras psicológicas completas de Sigmund Freud (Vol. 18, pp. 81-154). Rio de Janeiro: Imago, 1996. (Publicado originalmente em 1921).

Freud, S. (1939/1996). Moisés e o monoteísmo. In J. Salomão (Trad.), Edição standard brasileira das obras psicológicas completas de Sigmund Freud. (Vol. 23, pp. 13-67). Rio de Janeiro: Imago, 1996. (Publicado originalmente em 1939).

Lacan, J. (1957-1958/1999). O seminário: livro 5: as formaçôes do inconsciente. Rio de Janeiro: Zahar, 1999. (Publicado originalmente em 1957-1958).

Lacan, J. (1959-1960/2008). O seminário: livro 7: a ética da psicanálise. Rio de Janeiro: Zahar, 2008. (Publicado originalmente em 1959-1960).

Lacan, J. (1960-1961/1992). O seminário: livro 8: a transferência. Rio de Janeiro: Zahar, 1992. (Publicado originalmente em 1960-1961).

Lacan, J. (1961-1962/2003). O seminário: livro 9: a identificação. Recife: Centro de Estudos Freudianos do Recife, 2003. (Publicado originalmente em 19611962).

Lacan, J. (1962-1963/2005). O seminário: livro 10: a angústia. Rio de Janeiro: Zahar, 2005. (Publicado originalmente em 1962-1963).

Lacan, J. (1963/2005). Nomes do Pai. Rio de Janeiro: Zahar, 2005. (Publicado originalmente em 1963).

Lacan, J. (1971-1972/2011). O seminário: livro 19: .. ou pior. Rio de Janeiro: Zahar, 2011. (Publicado originalmente em 1971-1972).

Lacan, J. (1973-1974). O seminário: livro 21: les non-dupes errant. (inédito).

Lacan, J. (1974-1975). O seminário: livro 22: R. S. I. (inédito).

Miller, J.-A. (2011). De la naturaleza de los semblantes: los cursos psicoanalíticos de Jacques-Alain Miller. Buenos Aires: Paidós. 
Porge, E. (2010). Lettres du symptôme: versions de l'identification. Toulouse: Érès. 